\title{
First report of Ilyocryptus paranaensis inarmatus Kotov, Elíaz-Gutiérrez \& Gutiérrez-Aguirre, 2001 (Cladocera, Anomopoda, Ilyocryptidae) in South America
}

\author{
Sousa, FDR. ${ }^{a, b *}$ and Elmoor-Loureiro, LMA. ${ }^{b *}$ \\ aPrograma de Pós-graduação em Ecologia, Universidade de Brasília - UnB, Brasília, DF, Brazil \\ ${ }^{\mathrm{b}}$ Grupo de Estudos de Ecossistemas Aquáticos, Laboratório de Zoologia, Universidade Católica de Brasília - UCB, \\ QS 7, Lote 1, Bloco M, Sala 331, CEP 71966-700, Taguatinga, DF, Brazil \\ *e-mail: sousa_bio@yahoo.com.br; lourdes@ucb.br
}

Received April 27, 2011 - Accepted May 10, 2011 - Distributed November 30, 2011

(With 4 figures)

Ilyocryptus paranaensis Paggi 1989 was described initially from the Paraná River basin, Argentina (Paggi, 1989) and is distinguished from other neotropical Ilyocryptids by complete molting and the presence of a horn-like protuberance on each valve. This taxon is composed of two subspecies: Ilyocryptus paranaenis paranaensis Paggi 1989 and Ilyocryptus paranaensis inarmatus Kotov, ElíasGutiérrez \& Gutiérrez-Aguirre, 2001 the latter reported only for the basin of the Usumacinta River, Mexico (Kotov and Stifter, 2006).
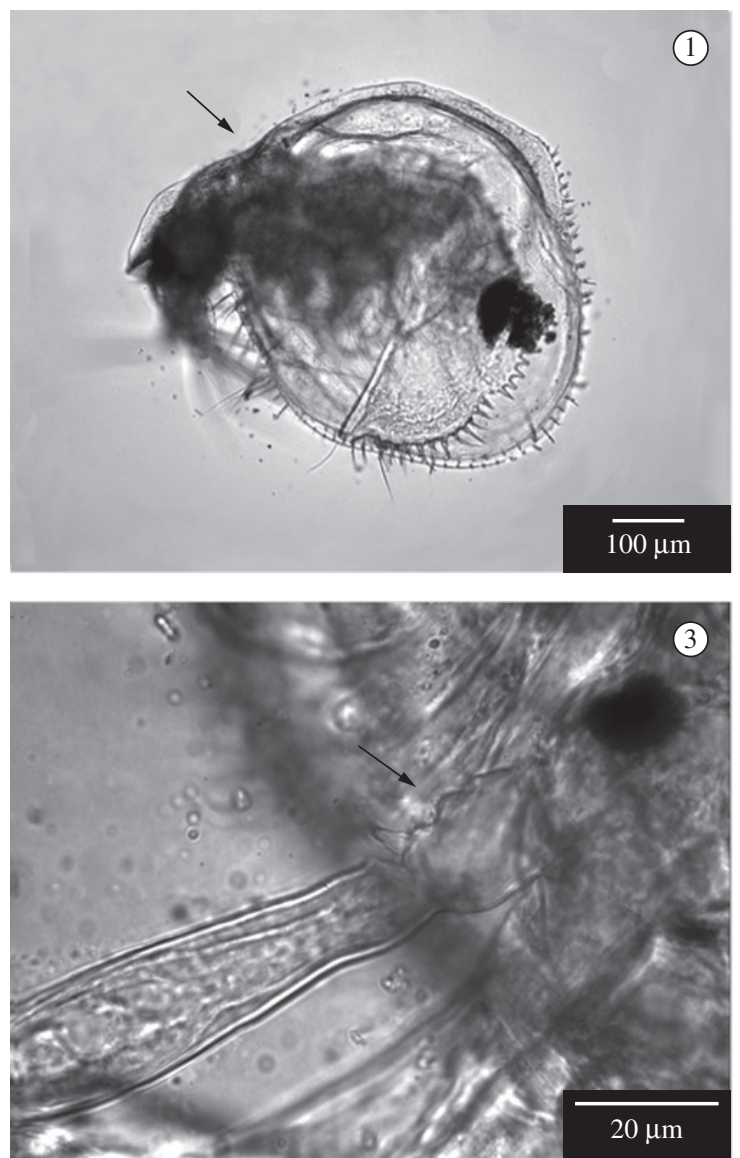

Until now, I. paranaensis paranaensis has been considered the only species occurring in South America, with reports from Argentina (Paggi, 1989; Frutos and Carnevali, 2008) and Brazil (Kotov and Elmoor-Loureiro, 2008).

During an inventory of cladocerans in streams of the Brazilian Cerrado (Project to Reestablish Ecological Integrity and Eco-management of the São Francisco and Paranoá River Basins - Reestabelecimento da Integridade Ecológica e Eco-gestão das Bacias do Rio São Francisco e Paranoá, FNMA), we observed the occurrence of
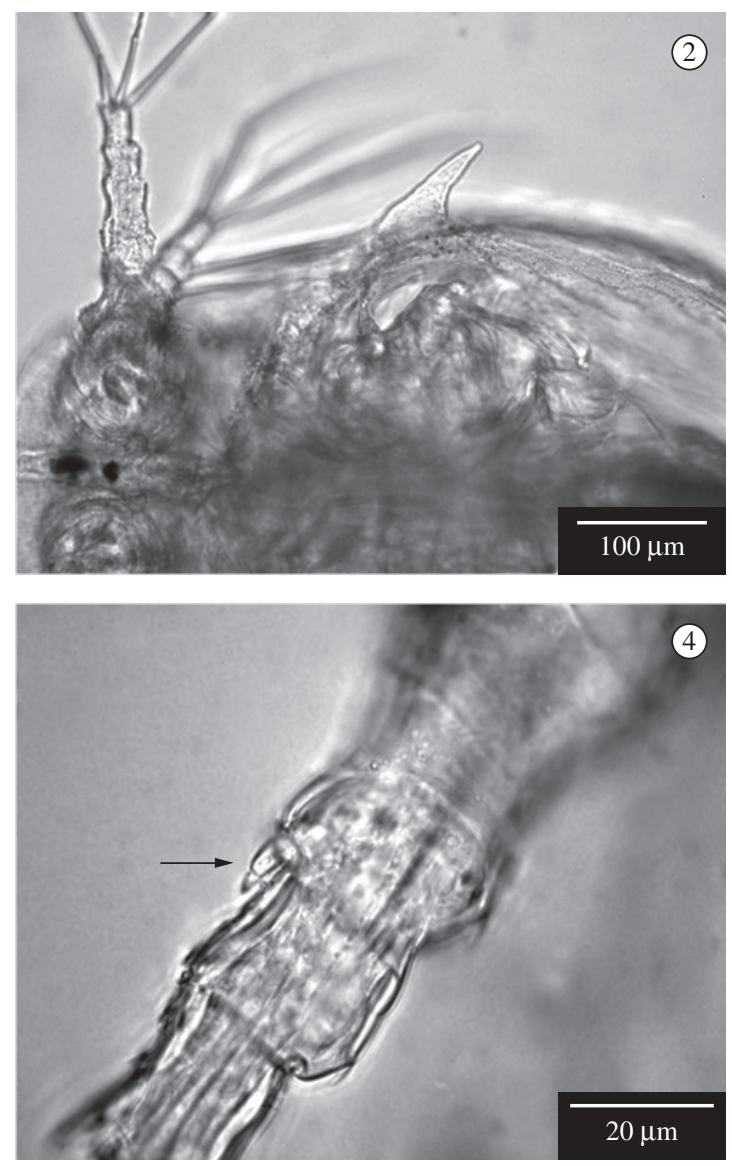

Figures 1-4. Ilyocryptus paranaensis inarmatus, parthenogenetic female from Federal District, Brazil. 1) Lateral view, arrow $=$ depression between head and valves; 2) Protuberance horn-like on right valve; 3) Antennule, arrow = system of hillocks; 4) Antenna, arrow = spine bisegmented on second segment of exopod. 
Ilyocryptus paranaensis inarmatus, representing the first record for South America.

A single specimen of $I$. paranaensis inarmatus was found in a sample taken with a plankton net (100 $\mathrm{mm}$ mesh) among submerged macrophytes and fixed with $4 \%$ formalin, during the dry season (August/2009) in Mestre D'Armas stream $\left(15^{\circ} 39^{\prime} 40,4^{\prime \prime} \mathrm{S}\right.$ and $\left.47^{\circ} 40^{\prime} 38,1^{\prime \prime} \mathrm{W}\right)$, in the Federal District, Brazil (0.37 m deep, pH 6.2, electric conductivity $134.9 \mathrm{mS} / \mathrm{cm}$, dissolved oxygen $2.27 \mathrm{mg} / \mathrm{L}$, current velocity $0.5 \mathrm{~m} / \mathrm{s}$ ). The voucher specimen is deposited in the Zoology Laboratory at the Universidade Católica de Brasília.

The observed specimen, a $722 \mathrm{~mm}$ long parthenogenetic female, presented diagnostic features of I. paranaensis inarmatus: complete molting, well-defined depression between head and valves (Figure 1), presence of horn-like protuberance on valves (Figure 2), antennules with well developed system of hillocks (Figure 3), antennas with spine second segment exopod bisegmented (Figure 4), and absence of spinules on the inner margin valves. Nevertheless, four denticles were observed at the base of the postabdomen, contrasting with the typical population, in which these denticles are absent, or reduced (Kotov and Stifter 2006).

The present record expands the occurrence of I. paranaensis inarmatus, which was originally thought to be restricted (Kotov et al., 2001). Furthermore, the difference observed in the number of basal denticles on the postabdomen suggests that studies on intra- and interpopulational variability are necessary in order to achieve a better understanding of the I. paranaensis subspecies.

Acknowledgements - The authors thank members of the GEEA (Aquatic Ecosystems Study Group - Grupo de Estudos de Ecossistemas Aquáticos) for their help with the field work. This study was financially supported by the Fundo Nacional do Meio Ambiente (FNMA).

\section{References}

FRUTOS, SM. and CARNEVALI, R., 2008. Zoo-heleoplankton structure in three artificial ponds of North-eastern Argentina. Revista de Biología Tropical, vol. 56, p. 1135-1147.

KOTOV, AA. and ELMOOR-LOUREIRO, LMA., 2008. Revision of Ilyocryptus Sars, 1862 (Cladocera: Ilyocryptidae) of Brazil whit description of two new subspecies. Zootaxa, vol. 1962, p. 49-64.

KOTOV, AA. and STIFTER, P., 2006. Cladocera: Family Ilyocryptidae (Branchiopoda: Cladocera: Anomopoda). Leinden: Backhuys Publisher. 172 p.

KOTOV, AA., ELÍAS-GUTIÉRREZ, M. and GUTIÉRREZAGUIRRE, M., 2001. Ilyocryptus paranaensis inarmatus subsp. nov. from Tabasco Mexico (Cladocera, Anomopoda). Crustaceana, vol. 74, p. 1067-1082. http://dx.doi.org/10.1163/15685400152691115

PAGGI, JC., 1989. A new species of Ilyocryptus (Anomopoda: Macrothricidae) from Argentina. Hydrobilogia, vol. 182, p. 239248. http://dx.doi.org/10.1007/BF00007518 